\title{
Zaglavska zadužbina sv. Mihovila iz očišta Grgura Mrganića*
}

\begin{abstract}
Na osnovi odnosa zadarskog trgovca Grgura Mrgnića s franjevcima trećorecima, osobito njegove zadužbine na Zaglavu na Dugom otoku, sagledava se širi kontekst društvenog položaja imućnog pučanina u Zadru nakon obnove mletačke vlasti u prvoj polovini XV. stoljeća.
\end{abstract}

Samostan sv. Mihovila na Zaglavu na Dugom otoku osnovan je polovinom XV. stoljeća zagovorom i neophodnom financijskom pomoći uglednog zadarskoga trgovca Grgura Mrganića. Na upravu franjevcima trećorecima predan je 1452., koji su ga, uzdajući se u sv. Mihovila, posvetili 1458. te je tako ubrojen među istočnojadranske samostane koji trajno djeluju sve do današnjih dana. ${ }^{1}$

Gradnja crkve i samostana te prvi spomeni trećoredaca u Zaglavu primjereno su historiografski obrađeni. Ponajbolje su to učinili Petar Runje i Emil Hilje, ${ }^{2}$ koji samostan spominju u kontekstu istraživanja umjetničke i glagoljaške baštine, a 1998. samostanu i mjestu posvećen je i opsežan zbornik s više radova, također iskoristivih za ovu temu. ${ }^{3} \mathrm{U}$ tim se istraživanjima gotovo jednodušno Mrganićeva uloga u postanku crkve i samostana svodila na okvire dobročinstva i brige za vlastiti onozemaljski život. Štoviše, izvan tog okvira nisu bitno izašli ni Roman Jelić ni Tomislav Raukar koji su se potanje bavili Mrganićevim životom i djelom. ${ }^{4} \mathrm{U}$

* Rad je financiran iz znanstvenog projekta Hrvatskoga katoličkog sveučilišta Porijeklo, strukture i percepcije društvenih elita hrvatskoga srednjeg i ranog novog vijeka (HKS-2016-1).

1 Samostan je, doduše, bio privremeno zatvoren 1843.-1888; usp. IVANČIĆ 1910: 211; RUNJE 1998: 27-28.

2 RUNJE 1998; HILJE 2003; usp. i IVANČIĆ 1910: 209-212.

3 ČUKA Dino, MILANJA Cvjetko, ŠPRALJA Izak (ur.). 1998. Zaglav: 600 godina prvog spomena: 540 godina posvete crkve svetog Mihovila Arhanđela. Zaglav: Općina Sali.

4 Usp. JELIĆ 1960; RAUKAR 1977: passim; FABIJANEC 1999: 56-59; Ista 2004: passim. Valja spomenuti da su te radnje nastale na omanjem broju podataka od ukupnih sačuvanih o Mrganiću u spisima zadarskih bilježnika. Brojnost tih podataka tolika je da zavređuje detaljnu i samostalnu obradu. O tome više u nastavku. 
nastavku ću stoga pozornost usmjeriti k širem kontekstu Mrganićeva čina, ponajprije njegova društvenog značenja. Naime, iz zadužbine se, osim dobročinstva, iščitava i realnost koja za dotadašnji društveni položaj pučana u srednjovjekovnom Zadru nije bila ni moguća ni uobičajena, a što je, pak, posljedica novih praktičnih društvenih relacija nakon obnove mletačke vlasti nad Zadrom 1409. i istočnojadranskom obalom tijekom prve polovine XV. stoljeća. Taj temeljni suodnos pretpostavke i hipoteze sagledat ću najprije kroz neke prakse mletačke uprave nad Stato da Mar, a potom kroz prizmu Grgurovoga društvenog položaja u Zadru i njegovih veza s franjevcima.

$* * *$

Za kontekstualiziranje zbilje mletačke uprave nad prekomorskim stečevinama ovom su prilikom iznimno svrsishodna razmatranja Sally McKee o mletačkoj Kreti i Monique O'Connell o temeljnim postavkama mletačke administrativne uprave nad prekomorskim stečevinama. ${ }^{5}$ Sumirajući zaključke obiju autorica - pri čemu težište ipak treba staviti na one O'Connell, s obzirom na to da je Kreta u mnogočemu bila specifična mletačka stečevina - oblikuje se slika osnovnih silnica mletačke kasnosrednjovjekovne uprave. U središtu opstanka te uprave nalazilo se uspješno balansiranje između poštivanja lokalnih (pravnih) običaja s normativnim vrijednostima i političkim nakanama mletačke središnjice. To je, pak, za sobom na lokalnoj razini podrazumijevalo istančano društveno pozicioniranje i ophođenje mletačkih upravitelja, ponajprije kneza. U postizanju efektivnog funkcioniranja zajedništva takav je upravitelj morao voditi računa o agendama različitih društvenih slojeva, skupina i moćnih pojedinaca, pri čemu mu je kao najbitniji kontrolni element očuvanja funkcionalnog zadovoljstva zajednice služio učinkovit mletački sudski sustav. U praksi je to često uključivalo i iskorištavanje tinjajućeg sukoba između plemića i pučana na lokalnoj razini, a ponajprije osobnog vezivanja pojedinaca, bez obzira na njihov društveni status, uz mletačke vlasti putem raznih pogodnih potvrda ili nagrada, ili bržim i izravnijim putem, poput orođivanja ili službe. ${ }^{6}$ Upravo na izravnoj, osobnoj razini, navedeni fenomen funkcioniranja mletačke vlasti valja blisko povezati s konceptom postanka i opstanka društvenih mreža te pridavanja velikog značenja različitim oblicima međudruštvene osobne povezanosti (engl. relatedness) - od političke do prijateljske razine - onkraj okvira krvnog srodstva ili svojtanskih veza. ${ }^{7}$

\section{MCKEE 2000; O’CONNELL 2009.}

6 Dovoljno je prisjetiti se primjera zadarskih plemića Matafarisa, Begna ili Grisogona; usp. O'CONNELL 2009: 64-65; ANČIĆ 2009.

7 Ulazak u detaljiziranje funkcioniranja srednjovjekovnih društvenih mreža ili koncepta povezanosti prelazi okvire rada. Štoviše, literatura koja se bavi različitim aspektima bilo jednog ili drugog iznimno je opsežna, pa ovom prilikom upućujem na osnovna djela (s daljnjim pregledima relevantne literature) za daljnje istraživanje: WASSERMAN I FAUST 1994; SCOTT 2000; HASELDINE 2013; DEVERE 2013; CARSTEN 2000; BOWDON 2004; MULLETT 2005. 
Sagledavajući sve navedeno razvidna je iznimna kompleksnost društvene zbilje izložene trajnom djelovanju mletačkog predstavnika vlasti. U njoj su početne ili naslijeđene društvene pozicije (odnosno pripadnost plemićkom ili pučanskom sloju) bile samo ishodišna, nikako ne i konačna točka za daljnje društveno pozicioniranje. Štoviše, takav je sustav - i mimo uvijek prisutne represivne kontrole (ponajprije u vidu vojnih odreda), koja se u krajnjim trenucima naprezanja aktivirala - trajno i vješto afirmirao mletačku vlast.

No, u takvom složenom sustavu bilo kakva javna manifestacija koja je izlazila izvan okvira uobičajene zbilje nije se mogla odviti bez spoznaje i barem prešutne suglasnosti ključnih društvenih čimbenika, pa susljedno i samih predstavnika mletačkih vlasti. Istodobno, u slučaju izostanka protivnih svjedočanstva, za osobe povezane $\mathrm{s}$ takvim manifestacijama s pravom se može pretpostaviti društvena umreženost s ključnim pojedincima upravnog aparata.

Upravo u tom kontekstu razmotrit će se i značaj Mrganićeva čina osnivanja zaglavskog samostana, uz, ipak, nekoliko uvodnih napomena. Tek se od predstojećih istraživanja očekuje puna potvrda ovdje iznesenog koncepta. Naime, Grgur Mrganić je za aktivnog poslovnog vijeka jedna od najučestalije zabilježenih osoba u spisima zadarskih bilježnika. Stoga će se tek temeljitim istraživanjem svakodnevnih okolnosti u kojima se Mrganić spominje razotkriti njegova međudruštvena osobna povezanost te pripadnost društvenim mrežama. Za sada se u nastavku nešto više može reći o njegovoj bliskoj povezanosti s franjevcima trećorecima te o njegovim krvnim rodbinskim vezama. Stoga ću prozopografskom metodom najprije nešto više reći o Mrganićevu podrijetlu te analizirati njegov položaj u zadarskom društvu, što ću potom povezati sa spomenutim činom darivanja polovinom XV. stoljeća.

Grgur je bio sin Stanislava, zvanog Mrgan - nadimak koji je vjerojatno dobio zahvaljujući pozamašnom stasu - i unuk Križana Smolića. ${ }^{8}$ Svi su pripadali hrvatskom plemićkom rodu Virevića iz Lučke županije, kojem je središte bilo u selu Jagodno, a ponajviše posjeda imali su ondje te u susjednim selima Miranje Gornje i Donje. ${ }^{9}$ Kao i pojedini pripadnici većine hrvatskih plemićkih rodova, i ogranak Virevića svoj je životni put pronašao u Zadru. ${ }^{10} \mathrm{~S}$ obzirom na središnju

Usp. BARNARD I GOOD 1984; za širu perspektivu McNEILL I McNEILL 2003; i ponešto, premda izlazi izvan strogih znanstvenih okvira, BARABÁSI 2002.

8 IT-TP ACI: dok. 2, str. 14-16 (13. XI. 1404.)

9 MAJNARIĆ 2012: 105-108; usp. ANTOLJAK 1992: passim.

10 O ograncima hrvatskog plemstva u Zadru tome usp. MAJNARIĆ 2014. Također o tom fenomenu usp. ANČIĆ: 1997; KARBIĆ 2000: 277-298. 
administrativnu i gospodarsku uloga Zadra od polovine XIV. stoljeća, ali i trajnu povezanost plemstva s najbližim središtem, tomu se ne treba čuditi.

Čini se da je najraniji pripadnik ogranka Smolića u Zadru zabilježen oko polovine XIV. stoljeća. Riječ je o Saracinu Smoliću, vjerojatno bratu Grgurova djeda Križana. ${ }^{11}$ Činjenica da je Saracin tada trgovao s uglednim zadarskim draparijem Mihovilom - vjerojatno najimućnijim Zadraninom svojega doba, koji je, među ostalim, u posjedu imao knjige mnogih znamenitih autora, poput zbirke Ezopovih basni, Albucasis Al-Zahrawijeva djela Al-Tasrif ili Danteove Božanstvenu komediju, a u slobodno vrijeme igrao šah (što je najstariji podatak o toj igri na istočnojadranskom području) ${ }^{12}$ - svjedoči o Saracinovim financijskim mogućnostima, ali i o određenom dosegu poduzetničkih aktivnosti.

Na neki pobliže neutvrđeni kontakt Virevića s draparijem Mihovilom može se pomišljati i s obzirom na činjenicu da je Mihovil imao posjede u Jošanima Velikim i Jošanima Malim, upravo ondje gdje su posjede imali i Virevići. ${ }^{13}$ Štoviše, Mihovilovi posjedi ondje su graničili s posjedima nekih Virevića, među kojima je izrijekom naveden samo stanoviti Mladočević Virević. ${ }^{14}$

Čini se, međutim, da je postojalo i izravnije zemljišno poslovanje između Mihovila i Virevića, no ono nije tako očito. Naime, među ispravama u Mihovilovu posjedu, a koje su nakon njegove smrti zabilježene u inventaru, nalaze se dvije ninskog javnog bilježnika Ivana Boršića, sastavljene 2. prosinca 1372., prema kojima Stojša, zvan Banić, Stojšić iz Miranja od roda Virevića daje posjede u Jošanima u zakup braći Mateju i Henriku pokojnog Radoslava iz Jošana. ${ }^{15}$ Premda o navedenoj braći nisu uočeni drugi podaci, pa se o njihovu mogućem odnosu s Mihovilom ne može ništa pobliže utvrditi, ipak je u kontekstu posjedovnih odnosa zanimljivo da se dvije isprave koje sadržajno nemaju veze s Mihovilom nalaze u njegovu posjedu. No, s obzirom na ostale isprave inventara koje se odnose na Jošane, može se pretpostaviti o čemu je riječ. ${ }^{16}$ Naime, Mihovil je u Jošanima imao vinograde, a vjerojatno se u okolici sela napasalo i njegovo stado, pecudes duodecim aliqe albe alique nigre cum octo agnis. ${ }^{17}$ Područje za uzgoj loze Mihovil

11 Usp. INVENTAR: br. 283, str. 188; br. 395, str. 208. Neki se Saračinići spominju u Zadru već od 1332., no njihova veza s Virevićima tom prilikom ne može se utvrditi (usp. CD CDS, 10: dok. 17, str. 19 (19. VI. 1332.)).

12 Usp. INVENTAR: br. 53-54, str. 87; STIPIŠIĆ 1984; Isti 2000: 18-20; JANEKOVIĆ RÖMER 2014: 54-57. O Mihovilu usp. JANEKOVIĆ RÖMER 2014; Ista 2013; STIPIŠIĆ 2000: 9-34.

13 Npr. usp. IT-TP ACI: dok. 56, str. 106-107 (14. IX. 1414.). Također više vidi u MAJNARIĆ 2012.

14 INVENTAR: br. 70, str. 138; br. 94, str. 146; br. 96, str. 146-147.

15 Isto: br. 69 , str. 138 ; br. 152, str. 160-161.

16 Uz isprave zabilježene u inventaru, koje su navedene u prethodnim dvjema bilješkama, na Jošane se odnosi i ona u INVENTAR: br. 99, str. 147.

17 Usp. INVENTAR: br. 40. 
je nastojao okrupniti, ${ }^{18}$ pa se upravo u tom pogledu mogu tumačiti dvije isprave u vezi s posjedima Stojše, zvanog Banić, Stojšića. S obzirom na to da nema preciznijih podataka, postoji nekoliko mogućnosti zašto i kako su one završile u Mihovilovu posjedu, no sve te mogućnosti u konačnici vode $\mathrm{k}$ okrupnjenju Mihovilova posjeda u Jošanima. Spomenute je posjede mogao kupiti od Stojše Banića Stojšića, pri čemu je dokument kupoprodaje izgubljen, a uživanje obveza zakupa prenijelo se na Mihovila. No, s obzirom na uredno čuvanje Mihovilu važnih isprava - o čemu svjedoči inventar - teško je povjerovati da bi se dokument kupoprodaje zagubio, pa je to malo vjerojatno. Bliža je mogućnost da je Stojša Banić Stojšić Mihovilu dugovao neku svotu novca uime nekog njihova danas nepoznatog poslovanja. Za naknadu te svote Stojša je sporazumno na Mihovila prenio vlastitu dobit koju je trebao ostvariti na temelju čina davanja u zakup - za njegova trajanja - svojih posjeda braći Mateju i Henriku pokojnog Radoslava, a utanačenim spomenutim ispravama pred bilježnikom Ivanom Boršićem. Pritom su isprave zapravo služile Mihovilu kao svojevrsni zalog u slučaju da u sporazumu sa Stojšom nešto krene naopako. U svakom slučaju, i tako je Mihovil okrupnjivao svoj posjed, doduše, ne trajno.

Osim toga, slučaj ukazuje na to da je Mihovil poslovao sa Stojšićima koji su, uz Smoliće, najbolje dokumentirani, ali i društveno najistaknutiji ogranak Virevića. Na temelju toga, a u kontekstu stvaranja poslovnih mreža, valja pretpostaviti i još neka danas nepoznata poslovanja Mihovila i Smolića, a što se opet može sagledati kao svojevrsni put k društvenoj prisutnosti Smolića u Zadru. Na to ukazuje i stotinjak godina poslije nastala oporuka Grgura Mrganića, koja svjedoči o i tada čvrstim vezama Smolića i Stojšića. ${ }^{19}$

Da su Smolići postali društveno prisutni u Zadru jasno je vidljivo iz položaja Saracinova sina Šimuna, koji je zasad u vrelima uočen u Zadru trajno od 1394. do $1444 .{ }^{20}$ Pritom je obavljao razne gradske administrativne poslove, a barem do uspostave mletačke vlasti nad Zadrom 1409. i ugledne kraljevske dužnosti. Tako je 1405. zabilježen kao homo regius, odnosno povjerenik Baldasara de Capresija, namjesnika kralja Ladislava u Ugarskoj i Hrvatskoj i zadarskog kneza. ${ }^{21}$ Čini se da se upravo u toj službi donekle nazire društveni krug unutar kojeg se Šimun kretao, odnosno unutar kojega ga je ta služba učvrstila. Taj je, čini se, obuhvaćao viši sloj građanstva, bliskog središnjim vlastima, a iz kojeg su te vlasti prema

18 Usp. Isto: br. 70, str. 138.

19 Usp. OPORUKA: 504.

20 Valja, kao i u slučaju Grgura Mrganića, istaknuti da tek predstoji pomnije istraživanje njegova položaja i poslova tijekom trećega i četvrtog desetljeća XV. stoljeća. Za najraniji spomen usp. Državni arhiv u Zadru (dalje: DAZd), Zadarski bilježnici (dalje: ZB), AR, b. II, fasc. 6, 200 (7. III. 1394.); za najkasniji DAZd, SZB, NB, b. II, fasc. 1, sv. 3, 11'-12' (7. V. 1444.).

${ }^{21}$ IT-TP ACI: dok. 17, str. 38-40 (30. V. 1405.). 
potrebi upošljavale različite administrativne službenike. Štoviše, Šimunov se krug nazire i iz činjenice da bio jedan od izvršitelja oporuke Katarine, supruge Bartola iz Sarzane, javnog bilježnika na službi u Zadru. ${ }^{22}$ Godine 1444 . sastavio je oporuku, kojoj je jedan od izvršitelja bio Grgur Mrganić, njegov bratić u drugom koljenu. ${ }^{23}$

Sličan položaj Saracinovu imao je i njegov bratić, spomenuti Stanislav, zvan Mrgan. Prvi sam ga put u dokumentarnim izvorima uočio 1390. te se kao aktivni trgovac u Zadru spominje do $1412 .{ }^{24} \mathrm{U}$ početnim godinama spomena u Zadru katkad je zabilježen s mjesnim pridjevkom de Iagodno, a osim pri kupoprodajama, čini da je zarana trgovao kapitalom. ${ }^{25}$ Kao i bratić, navodi se 1403. kao homo regius, odnosno povjerenik Alojzija de Aldemarisca, namjesnika kralja Ladislava u Ugarskoj, Dalmaciji i Hrvatskoj. ${ }^{26}$ Osim toga, čini se da je bio svojevrsni savjetnik Sudbenog stola Lučke županije u Podgrađu u slučajevima koje su ondje vodili stanovnici Zadra. ${ }^{27} \mathrm{U}$ svakom slučaju, Stanislav je udario temelje obiteljske imućnosti i ugleda u Zadru. Do drugog desetljeća XV. stoljeća razvidna je njegova opsežna trgovačka i kreditna djelatnost. Uz spomenutog Grgura, osnivača zaglavske zadužbine, Stanislav je imao još dvojicu sinova - Andriju i Balšu. Obojicu sam uočio samo jedanput u izvorima, Andriju 1402., ${ }^{28}$ a Balšu $1403 .{ }^{29} \mathrm{~S}$ obzirom na njihove jednokratne spomene, može se pomišljati na njihovu smrt u mladosti, a budući da se u izvorima spominju prije Grgura, možda su obojica bila Grgurova starija braća. Osim njih, imao je i kćer Katarinu, suprugu Pavla Dragoša od roda Polečića. ${ }^{30}$

Grgura sam u dokumentarnim izvorima uočio od 1408. nadalje. ${ }^{31}$ Tada se spominje kao trgovac pri sklapanju ugovora sa zadarskim marangonom Ivanom

DAZd, ZB, Teodorus de Prandino, b. VI, fasc. 1, 186-186' (25. IX. 1418.).

23 DAZd, ZB, Nicolaus de Benedicti, b. II, fasc. 1, sv. 3, 11'-12' (7. V. 1447.).

24 PP ACI: dok. 80, str. 204-206 (20. II. 1390.); DAZd, ZB, Teodorus de Prandino, b. I, fasc. 1, 294-295' (30. IX. 1412.).

25 Npr. usp. PS ACI: dok. 33, str. 87-88 (27. X. 1394.); DAZd, ZB, Artikucije iz Rivinjana, b. III, fasc. 8, 30 (23. III. 1401.); IT-TP ACIb: dok. 42-43, str. 186-187 (5. V. 1411.).

Godine 1401. spominje se stanoviti Jeorgium Mermonich kao jedan od pravnih zastupnika u sudbenim poslovima Filipa pokojnog Radiča iz Bičine od roda Lasničića (usp. ANČIĆ 2005: dok. IX, str. 76-77). Dvojbeno je može li se u toj osobi raspoznati Grgura Mrganića. Naime, s obzirom na izlaganje u nastavku odlomka, čini se malo vjerojatnim da je Grgur već 1401. imao dovoljno godina i bio dovoljno ugledan da bude pravni zastupnik. Osim toga, Filip Radič i ostali njegovi pravni zastupnici (Butko Petričević od roda Mogorovića, Vladiha Petrušević od roda Karinjana i Ratko Budonić od roda Prklja) generacijski su stariji od Grgura, pa je tim manja mogućnost da je osoba iz 1401. doista Grgur Mrganić. 
pokojnog Vučine oko dogradnje kuće u zadarskom predjelu sv. Platona. ${ }^{32}$ Ponovno je izdašnije zabilježen u izvorima 1412. Tom prilikom, radi razmatranja Grgurova položaja, osobito je zanimljivo njegovo ugovaranje trgovačkog pothvata koji je kreditirao zadarski građanin Krešo pokojnog Luke sa 749 zlatnih dukata. ${ }^{33}$ Naime, da bi ušao u pothvat Grgur je morao imati dopuštenje oca Stanislava, koje je i dobio. Iz spomenutih navoda može se ponešto zaključiti o Grgurovoj dobi. Naime, ako se oba slučaja motre sukladno s odredbama Zadarskog statuta o osamostaljenju sinova, a osobito ako su ti sinovi trgovci, is njihovim suodnosima s očevima, ${ }^{34}$ ali i s činjenicom da su muška djeca načelnu (pravnu) punoljetnost u Zadru stjecala s 15 godina života, ${ }^{35}$ može se zaključiti sljedeće. Grgur je vjerojatno 1408. imao oko 15 godina te je na temelju očeva pristanka postao samostalni trgovac. No, do pune punoljetnosti od 20 godina bio je dužan voditi obzira o uvjetima očeva pristanka, što je i vidljivo iz ugovaranja trgovačkog pothvata 1412. S obzirom na to, čini se da se Grgur rodio u prvoj polovini 90-ih godina XIV. stoljeća. Štoviše, to se zapravo preklapa s pojavom njegova oca Stanislava u zadarskim bilježničkim spisima, odnosno s njegovim preseljenjem u Zadar. Ako se k tomu prihvati zapis koji navodi Roman Jelić, ${ }^{36}$ Grgur se oženio 1419. S obzirom na podatke o potomstvu, može se pretpostaviti da se već tada oženio sa Stanom, koja se navodi u Grgurovoj oporuci. Relativno kasna dob ženidbe u suodnosu je s Grgurovim poslovima, odnosno sa stjecanjem mogućnosti za uzdržavanje obitelji, ali i s tadašnjim trendovima prema kojima su muškarci u brak ulazili u kasnijoj životnoj dobi. ${ }^{37} \mathrm{U}$ svakom slučaju, Grgur u trenutku pisanja oporuke 1460. nije imao muškog potomka. Štoviše, takvog nisam uočio u vrelima ni ranije, pa vjerojatno Grgur nije ni imao muškog potomka, barem ne onog koji je doživio punoljetnost. Oporuka bilježi nekolicinu njegovih kćeri: Pavlu, tada još djevojku, Katarinu, suprugu Dominika Sinkovića, i Dragu, suprugu stanovitog Petra. Jelić navodi da je Grgurova kći bila i Ljubica, supruga krojača Blaža, no u tekstu oporuke, na osnovi kojeg je Jelić i zaključivao, to nije nedvojbeno navedeno. ${ }^{38}$ No, još je bit-

32 DAZd, ZB, Artikucije iz Rivinjana, b. III, fasc. 10, 15'-16 (19. XI. 1408.). Isti se dan Grgur pojavljuje i kao svjedok pravnog čina koji je u registru bilježnika Artikucija iz Rivignana zabilježen neposredno prije Grgurova ugovora (DAZd, ZB, Artikucije iz Rivinjana, b. III, fasc. 10, 15 (19. XI. 1408.)).

33 DAZd, ZB, Teodorus de Prandino, b. I, fasc. 1, 294-295' (30. IX. 1412.).

34 ZS: knj. 2, g. 20.

35 ZS: knj. 2, g. 112; usp. knj. 2, g. 26-27.

36 JELIĆ 1960: 496-497. Jelić spominje spis (pohranjen među spisima samostana sv. Dominika) s nadnevkom 30. X. 1419., na kojem stoji regesta Scriptura contratus dotalis ad hereditatem Gregori Mergane civis Iadre, premda se sam dokument sadržajno ne odnosi na to što bilježi regesta.

37 Usp. npr. JANEKOVIĆ RÖMER 1999: 185; usp., doduše, za kasnije doba VEKARIĆ 1999: 29-46.

38 JELIĆ 1960: 497; usp. OPORUKA: 504. 
nije da Jelić spominje i izravnoga krvnog muškog Grgurova nasljednika. Naime, Jelić je držao da je Grgur imao brata Cvitana - i premda to nije izrekao - očito još jednog Stanislavova sina. Zaključak je temeljio na bilježničkom zapisu bilježnika Jakova pokojnog Ostoje iz 1436., a u kojem stoji recepisse a ser Georgio Mgdanich merzario tanquam guardiano fraternitatis $s$. Iacobi de Iadra. ${ }^{39}$ Taj je zapis povezao s Grgurovom oporukom u kojoj se navodi da polovinu svih kupljenih posjeda u Jagodnomu reliquid Georgio de Flore suo nepoti ${ }^{40}$ te ga tumačio u duhu tadašnjeg trenda iskrivljavanja hrvatskih imena i njihova prilagođavanja talijanskom, odnosno latinskom jeziku. ${ }^{41}$

Problem je Jelićeva tumačenja dvostruk. Najprije, zapis bilježnika Jakova Ostoje ne odnosi se na nekog Jurja Mrganića, nego zapravo na samog Grgura Mrganića. ${ }^{42}$ Naime, bilježnička pogreška u zapisima imena Gregorius i Georgius vrlo je česta, što povjesničara - kao i u Jelićevu slučaju - ako pojedine spise sagledava parcijalno, može navesti na krivi trag. ${ }^{43}$ Osim toga, ako se kroz zadarske bilježničke spise XV. stoljeća prati pojava i karijera pojedinca, teško je prihvatljivo da se određeni pojedinac prvi put - što bi bio slučaj pretpostavljenog Jurja Mrganića - pojavljuje tek u određenoj službi, a ponajviše kao gvardijan zadarske Bratovštine sv. Jakova Galicijskog. Naime, takva služba u uglednoj bratovštini utjecajnih pučana podrazumijevala bi već postignuti stanoviti vlastiti ugled u Zadru različitim pothvatima dostupnima pučanima, poput ponajprije trgovine i obrta. Stoga je mogućnost da se osoba prvi put u spisima zabilježi tek u uglednoj službi iznimno mala. Susljedno je zaključiti da se zapis bilježnika Jakova Ostoje odnosi na samog Grugra Mrganića. Jelićev je, pak, zaključak o trendovskim prezimenima prihvatljiv, no ipak valja naglasiti da zadarski trgovac Juraj de Flore najvjerojatnije nije pripadnik ogranka Smolića/Mrganića. Naime, ako mu je Stanislav Mrgan doista bio djed, teško je vjerovati da se ne bi identificirao pridjevkom Mrganić, a osobito ako bi bio jedini živući muški izdanak tog ogranka, što bi u tom slučaju proizlazilo iz Grgurove oporuke. Osim toga, Grgur oporukom, premda ne bilježi univerzalnog nasljednika, supruzi Stani ostavlja ono što bi se moglo očekivati da

39 JELIĆ 1960: 497.

40

41

42 
ostavi muškom nasljedniku, ako ga doista i ima. U tom je kontekstu vjerojatno Juraj de Flore, Grgurov nećak po supruzi. No, tek predstoji pomnija potvrda o Jurju de Floreu u zadarskim bilježničkim spisima XV. stoljeća. Naime, zasad je njegova određena bliskost s Grgurom vidljiva samo u činjenici da ga Grgur 1441. imenuje vlastitim zastupnikom u pravnim poslovima. ${ }^{44}$

Nakon ovih kratkih opaski o Grguru i njegovim precima - pri čemu, ponavljam, pomno istraživanje samog Grgura tek predstoji - pozornost valja usmjeriti na Grgurov pravni položaj i njegov odnos s franjevcima trećorecima.

Dok su Grgur i njegov otac Stanislav gospodarski prosperirali u Zadru, njihov društveni položaj ondje nije odgovarao onom u djedovini Virevića, odnosno u Lučkoj županiji Kraljevine Hrvatske. Naime, premda su u djedovini uživali plemićki status u gradskoj općini - društveno-pravno uređenoj nakon donošenja komunalnog Statuta i zatvaranja Velikog vijeća - nisu mogli imati istovjetni društveni status. Uzroke tome ponajprije valja tražiti u različitom procesu formacije i uvjetovanosti tzv. kraljevskoga od komunalnog plemstva, odnosno u gajenju pripadanja tradiciji antičkog civiteta i kontinuiteta priobalnoga grada među privilegiranim komunalnim slojevima, za razliku od svijeta koji tu tradiciju nije imao. ${ }^{45}$

U svakom slučaju, horizontalna društvena interakcija između kraljevskog i gradskoga plemstva, koja je doista i postojala, konačno je prekinuta najkasnije do 30-ih godina XIV. stoljeća, kada zatvaranjem Velikih vijeća u dalmatinskim gradskim općinama završava odjeljenje privilegirane društvene skupine, odnosno patricijata. S obzirom na to, hrvatski plemići, poput Grgura, u Zadru nikad nisu mogli biti plemeniti građani (nobilis ciuis), nego samo građani (ciuis), odnosno pučani. ${ }^{46}$ To je istodobno značilo da su bili isključeni iz svih političkih aktivnosti - nisu mogli birati ni biti birani - te većine gradskih upravnih službi.

U slučaju Zadra, a što se potvrđuje i u većini ostalih istočnojadranskih gradskih općina, dio je hrvatskih plemića unatoč tome svojim ugledom, društvenim i poslovnim vezama te gospodarskom moći najčešće zasjenjivao gradsko plemstvo.

44 DAZd, ZB, Iohannes de Calcina, b. VIII, fasc. 1, sv. 2 , 5 (26. VII. 1441.). Jurja de Florea spominje i HILJE 2005: 163.

45 Za ovu priliku od iznimno opsežne literature o procesima formacije plemstva dovoljno je uputiti na HERLIHY 1973; KARBIĆ 2006.

46 Ulazak u problem definiranja gradskih slojeva na osnovi društvene privilegiranosti (za razliku od definiranja na osnovi pravne kategorizacije) prelazi okvire zadane teme. Ovom prilikom stoga upućujem na ključne radove za ulazak u problematiku: RAUKAR 2007; PEŠORDA VARDIĆ 2007; BENYOVSKY 2007; JANEKOVIĆ RÖMER 1999: 49-56, 225-233, 283-289; FABIJANEC 2004: 57-73. O slučaju društvenoga i pravnog položaja hrvatskog plemstva u Zadru usp. MAJNARIĆ 2014: 216-228. 
Ti su hrvatski plemići zapravo tvorili sloj bogatoga građanstva te su se uglavnom posvetili trgovini, kreditiranju ili suknarstvu. Štoviše, među najuglednijim zadarskim trgovcima i suknarima druge polovine XIV. i tijekom XV. stoljeća prednjačili su oni hrvatskog podrijetla, poput već spomenutog draparija Mihovila Petrova ili trgovca Lovre Dražmilića od roda Jamometa. Sukladno s time, Stanislavov i Grgurov snažan gospodarski uzlet u Zadru ponajprije se može tumačiti na osnovi dobrih gospodarskih predispozicija koje je pripadanje hrvatskom plemstvu u pravilu podrazumijevalo. Njihovo, pak, etabliranje u Zadru posvjedočuje činjenica da u drugom desetljeću XV. stoljeća njihovo identificiranje nadimačkim prezimenom Mrganić istiskuje obiteljsku identifikaciju Smolić i onurodovsku Virević.

Činjenica da su bili isključeni iz političkog života grada među ostalim je pridonijela bližem povezivanju hrvatskih plemića inkorporiranih u zadarsko društvo s ostalim zadarskim imućnim građanstvom, što je rezultiralo organizacijom Bratovštine (ili Škole) sv. Jakova Galicijskog 1407. ${ }^{47}$ Potonja je od tada nadalje imala bitan utjecaj u zadarskoj svakodnevici, a pritom su joj upravo plemići iz zaleđa davali bitan ton, osobito Grgur Mrganić, koji je 1457. zabilježen kao prvi i najistaknutiji član Bratovštine, na čelu njezine uprave. ${ }^{48}$ Štoviše, Bratovštini je potkraj 40-ih godina XV. stoljeća dao sagraditi i privremeno sjedište, a ona je zauzela i bitno mjesto u njegovoj oporuci. ${ }^{49}$

U svakom slučaju, među upraviteljima Bratovštine 1457. raspoznatljivi su neki od najuglednijih zadarskih pučana XV. stoljeća (npr. spomenuti Lovro Dražmilić, protomajstor Šimun Bilšić, javni bilježnik Šimun Damjanov, bojadisar Lovor pokojnog Donata Milković, Grgurov zet - trgovac Dominik Sinković),${ }^{50}$ pa je samim time u svakodnevlju Zadra Bratovština bila bitna društvena sastavnica, donekle usporediva s dubrovačkom Bratovštinom sv. Antuna, premda o njezinu djelovanju nema ni približan broj podataka kao o potonjoj. No, činjenica da je Grgur Mrganić bio najistaknutiji član Bratovštine temu rada vodi do same srži.

$* * *$

Godinama je Grgur vodio različite poslovne pothvate, akumulirao bogatstvo te posjedovao brojne nekretnine u Zadru i njegovu distriktu u neposrednom zaleđu grada i na zadarskom otočju, ali i na području nekadašnje Lučke županije. Najsjajniji iskaz Grgurovoga društvenog značenja u zadarskom društvu postao je vidljiv 40-ih godina XV. stoljeća. Naime, premda se i ranije isticao kao dobro-

\footnotetext{
$\overline{47}$ Spomen osnivanja zabilježio je kroničar Pavao Pavlović; usp. LJETOPIS: 42.

48 Za prijepis popisa članova Bratovštine, koji je nastao pri reformaciji njezine matrikule 1458 ., usp. JELIĆ 1960: 498. Također usp. PEDERIN 1990: 19-20.

49 O tome više u nastavku rada.

50 Usp. JELIĆ 1960: 498. Također o Dominiku Sinkoviću usp. FABIJANEC 2004: 71.
} 
činitelj, njegovi najsjajniji, gotovo istodobni pothvati, koji su ujedno zahtijevali znatan novčani izdatak, bili su obnova crkve sv. Ivana Krstitelja i, uz nju, gradnja samostana za franjevce trećorece, podizanje hospitala uz katedralu sv. Stošije te gradnja crkve i kuće na Dugom otoku.

U prosincu 1439. zadarski nadbiskup Lovro Venier, na molbu Grgura Mrganića, dodijelio je crkvu sv. Ivana Krstitelja izvan zadarskih zidina franjevcima trećorecima. Crkva je prije toga bila nadarbina svećenika glagoljaša Pavla, no on se prava na nju odrekao. Pritom je nadbiskup spomenuo da je crkva u ruševnom stanju, a upravo se Grgur obvezo na njezin popravak, ali i na izgradnju nastambe (locus) uz crkvu. Štoviše, nadbiskup je Mrganiću podijelio ius patronatus nad spomenutom crkvom. ${ }^{51}$ Zapravo je u blizini crkve sv. Ivana Krstitelja od stoljeća ranije bio smješten lazaret kojim su rukovodili trećoreci, a i čini se da su, barem povremeno, živjeli i uz samu crkvu..$^{52}$ Štoviše, sam je Mrganić na početku 1439. izabran sindikom i prokuratorom lazareta, ${ }^{53}$ pa ga to, uz spomenuto patronatsko pravo, zapravo stavlja u poziciju ključnoga svjetovnog zaštitnika zadarskih trećoredaca, ali i dobročinitelja sirotih, nemoćnih i bolesnih u Zadru. Čini se da je svoju brigu za trećorece prenio i na sebi blizak krug ljudi, što donekle posvjedočuje i činjenica da spomenuti Šimun Saračinić oporučno - uz pomoć izvršitelja, krvnog rođaka Grgura Mrganića - ostavlja legat heremitis sancti Iohannis extra Iadram. ${ }^{54}$

Mrganićeva vizura zaštitnika marginaliziranih Zadrana još je postala sjajnija izgradnjom hospitala uz zadarsku katedralu. Uprava nad hospitalom trebala je biti prepuštena Bratovštini sv. Jakova, koja je ujedno u okviru hospitala trebala dobiti i sjedište, a u čitavom je kompleksu predviđena i gradnja crkvice sv. Jakova. Upravo ta gradnja posredno pokazuje Grgurov iznimni ugled te umreženost u tadašnjem zadarskom društvu. Naime, zagovor za dopuštenje te gradnje dala su obojica zadarskih rektora, knez Hektor Pasqualigo i kapetan Nikola Memo, a 1451. to je potvrdio dužd Francesco Foscari. Čini se da je gradnja hospitala završena do 1452., kada je ondje protomajstor Šimun Bilšić zidao zdenac, ${ }^{55}$ a Grgur je i oporučno ostavio niz odredbi o upravi i brizi za hospital.

Istodobno s gradnjom hospitala trajao je još jedan Grgurov pothvat. Riječ je o zadužbini na Zaglavu koji, dakako, nije odabran slučajno. Ondje su bili njegovi posjedi i njegovi seljaci kojima je bila potrebna pastoralna skrb, ${ }^{56}$ a Zaglav je pružao i određenu skrovitost neophodnu pustinjaštvu. Osim toga, ondje, za razliku

\footnotetext{
Usp. ISPRAVE: dok. 2, str. 4.

52 Usp. RUNJE 2012: 113-125.

53 Usp. Isto: 127-128.

54 Usp. DAZd, ZB, Nicolaus de Benedicti, b. II, fasc. 1, sv. 3, 11'-12' (7. V. 1444.).

55 Usp. JELIĆ 1960: 490.

56 Usp. RUNJE 1998: 14, gdje se na osnovi saznanja iz zadarskih bilježničkih spisa navode crtice o povezanosti Grgura Mrganića sa Zaglavom.
} 
od drugih otoka zadarskog distrikta, nije bilo samostana. Štoviše, čini se da su pojedini pustinjaci franjevački pokornici na Dugom otoku boravili od početka XV. stoljeća. ${ }^{57}$

Za radove na samostanskoj crkvi prvi su, doduše bezuspješni, ugovori sklopljeni u listopadu $1444 .{ }^{58}$ Grgur je tada od zadarskih marangona i muratora očekivao da na Dugom otoku iz temelja izgrade crkve sličnu onoj sv. Mateja u zadarskom predgrađu. No, s obzirom na to da je u ožujku ugovor poništen, očito tada od dogovorene gradnje nije bilo ništa. Čini se, međutim, da su majstori određeni dio posla ipak obavili, barem određene predradnje, jer sljedeći ugovor o gradnji crkve iz svibnja 1445. ne sadrži sve stavke potrebne gradnje kao ugovor iz 1444. Ugovor iz 1445. Grgur je sklopio sa zadarskim marangonima Vukom (Slavogostićem) i Jurjem Lukačevićem da u roku od godine dana na Zaglavu sagrade crkvu. Crkva je trebala biti stopu šira, dvije dulja od one sv. Mateja, s dvije i pol stope debelim zidom, od tamnog kamena, s kvadratnim svetištem s oltarom, zvonikom u obliku preslice, s dvoja vrata i dvama prozorima od bijelog kamena te prekrivena s cuppis seu planchis. Grgur se obvezao pribaviti sav potrebni materijal, a kao plaću graditeljima isplatiti vrijednost od 500 libara i 70 kvarti pšenice u trima obrocima, na početku, usred i nakon završetka radova.$^{59}$ Iduće, 1446. godine, Grgur je na Dugom otoku dao graditi i kuću. ${ }^{60}$ Može se pretpostaviti da je riječ o objektu koji je nekako bio povezan s izgradnjom crkve. Najposlije, 1452. sve izgrađeno dao je na upravu franjevcima trećorecima te ih obvezao da ondje trajno borave te da uz sebe imaju svećenika koji će svakodnevno slaviti službu Božju. ${ }^{61}$ Crkva je posvećena titularu sv. Mihovila 1458., o čem je ostao trag u natpisu na dovratniku. ${ }^{62}$

Sukladno s tim iznimnim pothvatima koji su nedvojbeno Grgura doveli u sam vrh zadarskog društvenog ugleda, ipak se nameće pitanje zašto se baš tad odlučio na njih. Premda se može pomišljati da je tek tada stekao dovoljni imutak za velike izdatke ili da je ušao u životnu dob koja ga je nagnala na drugačije poglede na svijet, čini se da to nisu bili presudni razlozi.

$* * *$

Tijekom 40-ih godina XV. stoljeća Mlečani su konačno zaokružili svoj posjed na istočnojadranskoj obali te u tamošnjim stečevinama provodili konsolidaciju

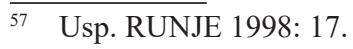

58 Usp. Prilog I; HILJE 2003: 17; FISKOVIĆ 1959: 44-45, 155.

59 Prilog II.

60 Usp. Prilog III; JELIĆ 1960: 489; HILJE 2003: 17.

61 Usp. Prilog IV; RUNJE 1998: 15-16.

62 Usp. PETRICIOLI 1974: 90-91; GRBIN 1988: 69-71.
} 
uprave. Ta se, kako je već spomenuto, u osnovi svodila na prispodobljavanje pravnih lokalnih posebnosti uzusima središnje uprave, no ipak uz njegovanje pojedinih posebnosti. Upravo se stoga oko tog doba kodificiraju npr. Vranski zakonik, Statut lige sela zadarskoga kneštva, Novigradski zbornik starohrvatskog običajnog prava, a s velikom pozornošću Mlečani se odnose i prema posebnostima kotorskoga Grblja. Štoviše, u tadašnjem zadarskom distriktu hrvatsko se plemstvo, na temelju kodificiranja lokalnih posebnosti Novigradskim zbornikom, ponovno započelo učestalije identificirati oznakom genusa te je tako na svojevrstan način pred mletačkim vlastima činilo reminiscenciju na svoja prava prije uspostave mletačke vlasti nad Zadrom i dijelom njegova zaleđa. ${ }^{63} \mathrm{U}$ takvom ozračju čini se mogućim da su se i zadarski građani, podrijetlom hrvatski plemići, isticanjem svojeg ugleda nastojali prikazati kao nezaobilazan društveni čimbenik mletačkim vlastima.

Upravo u tom kontekstu valja sagledati i djelovanje Grgura Mrganića, premda je njegova poruka mletačkim vlastima bila mnogostruko suptilnija. Naime, činovi brige za trećorece izvan zidina, osnivanje hospitala te gradnje crkve na Zaglavu, osim što su ovjekovječili Mrganića, pokazali su njegovu nepobitnu usredotočenost na opće dobro. Osim toga, izborom za sindika lazareta ušao je u povlašteni krug, s obzirom na to da su tu dužnost uglavnom obavljali zadarski plemići. No, zadužbinom na Zaglavu neprijeporno se svrstao uz bok osnivačima samostana isključivo iz redova zadarskoga plemstva. Do tada osnivači samostana nisu dolazili izvan plemićkog kruga, a dovoljno je spomenuti Milanove (osnivači samostana sv. Pavla na Školjiću/Galevcu), Grisogone (osnivači samostana sv. Duje u Kraju) ili Begne (osnivači samostana sv. Jerolim u Ugljanu). ${ }^{64}$ Štoviše, u tom kontekstu nije slučajno ili pogrešno da ga je dužd Francesco Foscari u potvrdi izgradnje hospitala oslovio Gregorius quondam Margani de domo Virevich, nobilis habitator civitatis Iadre (istaknuo autor). ${ }^{65}$

Osim toga, čini se da je Grgur imao i još jedan motiv pri dovođenju trećoredaca u Zaglav, a riječ je je o gajenju tradicije hrvatskog plemićkog podrijetla. Naime, od polovine XIV. stoljeća među hrvatskim plemstvom gaji se koncept samosvijesti o plemstvu kao jedinom političkom subjektu u Kraljevini. Ukratko, taj se koncept nadograđuje na poziciju dijela plemstva koje je ono uživalo u doba neprijeporne vlasti banova Šubića u Kraljevini Hrvatskoj potkraj XIII. i na početku XIV. stoljeća. Pojednostavnjeno govoreći, tada je upravo plemstvo okupljeno oko Šubića uživalo izniman položaj, a posredno je prihvatilo i ideju svete krune Hrvatskog kraljevstva te sebe motrilo kao jedine prave i pravne baštinike kralja Zvonimira,

\footnotetext{
63 O društvenom značenju i tumačenju termina genus usp. MAJNARIĆ 2015.

64 O tim zadužbinama više usp. HILJE 2003.

65 Za prijepis dukala usp. JELIĆ 1960: 501-502.
} 
odnosno „narodnih vladara“. ${ }^{66}$ Mjesto na kojem se osobito gajio taj koncept ponajprije u pogledu čuvanja pisane riječi i s obzirom na njezinu snagu tijekom kasnog srednjovjekovlja - bila je zapravo zadužbina knezova Šubića, odnosno franjevački samostan u Bribiru. ${ }^{67}$ Upravo se u odnosu Šubića i franjevaca može prepoznati uzus za Grgurov odnos prema trećorecima i njegovo dobročinstvo prema njima.

Kada se sve spomenuto ima na umu, širi kontekst Grgurova djelovanja i osnivanja samostana ukazuje na sljedeću sliku. U trenutku usklađivanja, odnosno kodificiranja i normiranja različitih lokalnih posebnosti sa središnjim institucionalnim zahtjevima u Mlecima, Grgur Mrganić je spomenutim činovima poslao jasnu sliku svojeg društvenog položaja. Njom se prikazao kao jednim od najbitnijih čvorišta zadarske društvene umreženosti, materijalizirao bliskost s predstavnicima mletačkih vlasti putem čega je, ističući hrvatsko plemićko podrijetlo, zadarskom gradskom plemstvu pokazao da mu njihov društveni status u osnovi nije potreban ni bitan. Upravo je to kontekst u kojem treba motriti i duždevo oslovljavanje Mrganića. Naime, nobilis habitator odnosi se na njegov hrvatski plemićki status te položaj stanovnika Zadra, što je, kako je ranije navedeno, u normativnom okviru odnosa gradskog ustroja i ustroja Hrvatske Kraljevine nespojivi oksimoron. No, mletačkim vlastima u prispodobljavanju lokalne tradicije normativima, a ponajprije i interesima središnjice nespojivo je postalo moguće i spojivo. Stoga je Grgur Mrganić bio plemić, prema kojem su se mletačke vlasti u svakom pogledu trebale tako i odnositi, no koji nije pripadao gradskom zadarskom patricijskom krugu. Štoviše, u očima mletačkih vlasti to je njegov položaj činilo atraktivnijim jer su mogućnosti praktične uporabe Grgura u horizontalnim ili vertikalnim društvenim intervencijama za mletačke vlasti bile lakše i veće, nego da se za to rabilo neku osobu s patricijskim statusom. Takva situacija iz aspekta upravnih vlasti izravno je praktično pridonosila obuzdavanju patricijskih težnji i zahtjeva. Mrganićev položaj istodobno je pružao uzoran primjer utjecajnim i imućnim pučanima - kojih je u gradu bio najistaknutiji predstavnik - da mogu biti subjekt vrijedan pozornosti mletačkim vlastima. Najposlije, svojom brigom za trećorece ukazao je da je upravo on osoba, kao što su to bili i Šubići, koja identitetski može okupljati i predstavljati hrvatsko plemstvo u Zadru.

Iz svega navedenog vidljivo je koliko je Grgur Mrganić bio sveprisutan i presudan za gradsku društvenu dinamiku. Stoga je susretljivost mletačkih vlasti prema Grguru Mrganiću u pojedinim okolnostima više nego razumljiva.

S obzirom, pak, na Mrganićevu ukupnu prisutnost u svakodnevlju grada, osobnu povezanost s pučanima koji su tvorili tkivo grada te bliskost s predstav-

\footnotetext{
66 O tome više u MAJNARIĆ 2012: 256-260.

67 KARBIĆ 2000: 303-317.
} 
nicima mletačkih vlasti - što mu je nudilo i više nego nadoknadu isključenosti iz političkog života grada - njegov osobni položaj u praksi bio je gotovo jednak onom patricijskom. Štoviše, u praksi je - dakako, uz dopuštenje mletačkih predstavnika - ne samo mogao učiniti isto što i gradski plemić, nego je to s obzirom na međudruštvenu povezanost $\mathrm{i}$ imućnost mogao učiniti uspješnije.

U širem kontekstu Grgurov primjer pokazuje nove okolnosti u društvenim prilikama nakon uspostave mletačke Stato da Mar u XV. stoljeću na istočnojadranskoj obali. Sukladno s njima poticala se unutardruštvena dinamika s ciljem ograničavanja povlaštene uloge plemstva, što je, poticanjem kretanja poput Grgurovih, poslužilo kao osnova za nekoliko stoljeća kasnije sudjelovanje pučana putem organiziranoga vlastitog vijeća u nekim vidovima političko-administrativnog života grada. Upravo buduća podrobnija istraživanja međudruštvene povezanosti te društvenih mreža trebala bi jasnije rasvijetliti društvenu dinamiku i ulogu mletačkih vlasti u njima.

Najposlije, Grgurova neraskidiva dobročiniteljska briga za samostansku zajednicu postojana je sve do današnjih dana, što je u konačnici, može se pretpostaviti, bilo i jest mnogostruko bitnije od kratkoročnih društvenih težnji.

\section{PRILOZI}

\section{I.}

18. X. 1444.

Grgur Mrganić ugovara sa zadarskim marangonima i muratorima Martinom Stravilićem i Tomom Veselićem uvjete gradnje crkve na Zaglavu na Dugom otoku. Ugovor je sukladno obostranom zahtjevu poništen 30. III. 1445.

(Državni arhiv u Zadru, Zadarski bilježnici, Simon Damiani, b. I, fasc. 1, sv. 5, 6'-7)

(6') $\mathrm{M}^{\circ} \mathrm{CCCC}^{\circ} \mathrm{XLIIII}{ }^{\circ}$, indictione $\mathrm{VIII}^{\mathrm{a}}$, die $\mathrm{XVIII}{ }^{\circ}$, mensis octobris, presentibus ser Mazolo de Gallelis et ser Iohannes de Begna nobilibus Iadrensibus, testibus et cetera

Egregius vir ser Gregorius Merganich ciuis et habitator Iadre, ex una parte, et magister Martinus Strauilich asserens se sui iuris et magister Thomas Vesselich, ambo marangoni et murarii, ciues et habitatores Iadre, ex alia parte, circa fabricam et constructionem infrascripte ecclesie fiende, ad has conuentiones et pacta solemniter peruenerunt, videlicet, primo nanque dicti magistri Martinus et Thomas sponte et ex certa scientia nulloque erore ducti, solemni stipulatione sine aliqua exceptione iuris uel facti, promiserunt, conuenerunt et se obligauerunt ipsi ser Gregorio ibi presenti, stipulanti et recipienti, hinc usque ad vnum annum proxime futurum facere, construere et fabricare de nouo a fundamento vnam ecclesiam de muro grosso pedibus duabus cum dimidio, laborato de lapide bruno, totam ad uoltum in Insola mangna ad Zaglaf in loco determinato, cuppis coperiendam, magnam, longam, altam et latam prout et sicut est ecclesia sancti Mathei extra et prope Iadram et latiorem ea intrinsecus medio pede, et ipsi ecclesie facere cuuam quadram 
longam pedibus octo, et campanille ab una canpana, et duas portas conuenientes, et unam fenestram quadram de lapide nouo albo scleto, ubi melius uidebitur ipsi ser Gregorio et ipsis portis facere ualuas, ad totam ipsam ecclesiam intrinsecus suffernare et extrinsecus imbocare, et cuppis coperire necnon totum corpus ipsius ecclesie penitus dare et assignare factum, constructum et expletum in omnibus et per omnia prout decet, et hoc omnibus suis magistria, manoalibus et aliis expensis oportunis et neccessariis pro ipso opere fiendo, exceptis dumtaxat infrascriptis expensis, quas facere et dare tenetur, et se obligauit ipse ser Gregorius ipsis magistris Martino et Thome prout inferius per ordinem declaratur. Et hoc ideo quia dictus ser Gregorius per se suosque heredes et successores sponte et ex certa scientia promisit et se obligauit dicitis magistris Martino et Thome dare et assignare, ibi ad locum ubi dictum opus fieri debet, calcem, arenam, cuppos, feramenta et omnia lignamina oportuna pro pontis et pro cintanis (?) ac pro ualuis et fenestra suprascriptis que pro ipsa ecclesia fabricanda et construneda fuerit neccessaria, et dare et soluere ipsis magistris pro eorum salario, labore, premio et mercede libras trecentas paruorum in numerata pecunia, et quartas centum frumenti boni et modia viginti boni vini, in hiis tribus terminis, scilicet terciam partem in principio operis et aliam terciam partem in medio dicti operis et reliquam terciam partem finito et per conpleto toto ipso opere. Que omnia et singula predicta dicte partes solemnibus stipulationibus hinc inde interuenientibus promiserunt uicissim, videlicet una pars alteri et altera alteri ad inuicem (7) firmam (!), rata et grata habere, tenere, attendere, obseruare, adimplere et in nullo contrafacere, dicere uel uenire, per se uel per alios aliqua ratione uel causa, modo aliquo uel ingenio de iure uel de facto, sub pena quarti euis de quo contrafactum fuerit et obligatione sui et omnium sourum bonorum mobilium et immobilium presentium et futurorum, cum reffectione damnorum omnium, interesse et expensarum litis et extra, qua pena soluta uel non nihilominus rata permaneant omnia et singula predicta. Actum Iadre sub logia domini capitanei prope portam terre firme.

(drugi rukopis) Ego Iohanes de Fanfogna iudex examinator Iadre me subscripsi (na margini) ser Iohanes de Fanfogna examinator

na margini (6'): 1445 die 30 marcii, indictione VIIIa presentibus ser Antonio quondam ser Iohannis de Grisogonis et ser Luciano de Calcina, nobilibus Iadre testibus ad hec uocatis et rogatis. Cassus et depenatus fuit presens contractus per me dictum notarium de uoluntate et consensu dictarum ambarum partium, scilicet dicti ser Gregorii et dictorum magistri Martini et magistri Thome marangonorum

\section{II.}

11. V. 1445.

Grgur Mrganić ugovara sa zadarskim marangonima Vukom (Slavogostićem) i Jurjem Lukačevićem uvjete gradnje crkve na Zaglavu na Dugom otoku.

(Državni arhiv u Zadru, Zadarski bilježnici, Simon Damiani, b. I, fasc. 2, sv. 2, 31-32)

(31) $\mathrm{M}^{\circ} \mathrm{CCCC}^{\circ} \mathrm{XLV}^{\text {to }}$, indictione $\mathrm{VIII}^{\mathrm{a}}$, die $\mathrm{XI}^{\circ}$, mensis maii, presentibus ser Nicolao de Nassis et ser Antonio Sincouich testibus et cetera

Egregius vir ser Gregorius Merganich ciuis et habitator Iadre, ex vna parte, et magister Lupus marangonus et magister Georgius Lucaceuich etiam marangonus, ciues et habitatores Iadre, ex alia parte, circa constructionem et fabricam infrascripte ecclesie fiende, ad has 
conuentiones et pacta solemniter peruenerunt, videlicet, primo nanque dicti magistri Lupus et Georgius, sponte et ex certa scientia nulloque erore ducti, solemni stipulatione sine aliqua exceptione iuris uel facti, promiserunt, conuenerunt et se obligauerunt ipsi ser Gregorio, ibi presenti, stipulanti et recipienti, hinc usque ad vnum annum proxime futurum facere, construere et fabricare in Insola magna ad Zaglaf in loco determinato vnam ecclesiam de muro laborato de lapide bruno, totam ad voltum (31') magnam, longam, altam et latam prout et sicut est ecclesia sancti Mathei extra et prope Iadram et latiorem ea intrinsecus medio pede et longiorem duobus pedibus et ipsi ecclesie facere murum grossum pedibus duobus cum dimidio et cuuam quadram longam pedibus septem et campanile siue turi ab una canpana, et duas portas, et duas fenestras de lapide albo nouo sceleto, et ipsis portis et fenestris facere ualuas, et unum altare maius in cuua, et totam ipsam ecclesiam intrinsecus suffernare et extrinsecus inbocare et cuppis seu planchis coperire, prout melius uidebitur et magis placuerit ipsi ser Gregorio, nec non totum corpus ipsius ecclesie penitus dare et assignare factum, constructum et expletum in omnibus et per omnia prout decet, et hoc omnibus suis magistria manoalibus et aliis expensis, pro ipso opere fiendo, oportunis et neccessariis, exceptis dumtaxat infrascriptis expensis, quas facere et dare tenetur et se obligauit dictus ser Gregorius ipsis magistris Lupo et Georgio prout inferius per ordinem declaratur. Et hoc ideo quia dictus ser Gregorius sponte et ex certa scientia promisit et se obligauit dictis magistris Lupo et Georgio dare et assignare ibi in loco ubi dictum opus fieri debet, calcem, arenam, plancas seu cuppos, plumbum et omnia feramenta oportuna et neccessaria pro ipso opere fiendo, et dare et soluere ipsis magistris pro eorum salario, labore, premio et mercede libras quingentas paruorum in numerata pecunia et quartas septuaginta frumenti boni in hiis tribus terminis, scilicet terciam partem in principio operis et aliam terciam partem in medio dicti operis et reliquam terciam partem finito et per conpleto toto ipso opere. Que omnia et singula predicta dicte partes solemnibus stipulationibus hinc inde interuenientibus promiserunt uicisim, videlicet una pars alteri et altera alteri adinuicem, firma, rata et grata habere, tenere, (32) attendere, obseruare, adimplere et in nullo contrafacere, dicere uel uenire, per se uel per alios aliqua ratione uel causa modo aliquo uel ingenio de iure uel de facto, sub pena quarti euis de quo contrafactum fuerit et obligatione sui et omnium suorum bonorum presentium et futurorum et cetera, qua pena et cetera. Actum Iadre ante apotecam ser Georgii de Flore.

(drugi rukopis) Ego Cressolus de Sope consiliarius domini chomitis Iadre me subscripsi (na margini) ser Cressius de Soppe consiliarius

\section{III.}

19. V. 1446.

Grgur Mrganić ugovara sa zadarskim marangonom Jakovom zvanim Zota, pokojnog Filipa, uvjete gradnje kuće na Dugom otoku.

(Državni arhiv u Zadru, Zadarski bilježnici, Simon Damiani, b. II, fasc. 3, sv. 1, 30-30’)

(30) $\mathrm{M}^{\circ} \mathrm{CCCC}^{\circ} \mathrm{XLVI}^{\circ}$, indictione VIIII ${ }^{\mathrm{a}}$, die XVIIII ${ }^{\circ}$, mensis maii, presentibus ser Donato de Zadolinis nobili Iadre et Micaele ad presens officiali ad dacium statere ciuitatis Iadre, testibus et cetera

Magister Iacobus marangonus quondam Philippi dictus Zota sponte et ex certa sciencia non per erorem, solemni stipulatione sine aliqua exceptione iuris uel facti promisit, conuenit 
et se obligauit ser Gregorio Merganich, ciui Iadre, ibi presenti et pro se suisque heredibus et successoribus stipulanti et recipienti hinc usque ad festum indulgentie sancti Simeonis iusti, scilicet die VIIIo mensis octobris proxime futurum, facere, construere et fabricare in Insola magna in loco determinato vnam domum de muro incalce magnam, longam et latam tantum quantum est magna, longa et lata illa altera domus quam eidem ser Gregorio dictus magister Iacobus fecit et construxit in dictam insola et latiorem ea intrinsecus tribus pedibus et longiorem aliis tribus pedibus, altam a tera (!) decem pedibus sine fundamento (30') et ipsi domui facere solare, parietes, tres portas et tres ualuas et fenestras oportunas et totam ipsam domum cupis coperire. Item facere eidem ser Gregorio vnam cisternam in illa fouea que ibidem iam cauata est, cui cisterne facere debeat et teneatur infundo et ubicumque in ea oportunum fuerit vnam taraciam bonam et sufficientem, ita et taliter quod a neutra parte penetrare debeat, sed bona et salda permanere, et hoc totum opus dare et assignare factum, constructum et expletum in omnibus et per omnia prout decet, omnibus suis magistria manoalibus et quibuscumque aliis expensis oportunis et neccessariis pro ipso opere fiendo, exceptis dumtaxat infrascriptis expensis quas facere et dare tenetur, et se obligauit dictus ser Gregorius ipsi magistro Iacobo vt inferius per ordinem declaratur, et hoc ideo per dictus ser Gregorius sponte et ex certa scientia promisit et se obligauit dicto magistro Iacobo sibi dare et assignare ibi in loco ubi dictum opus fieri debet, feramenta, cupos, lignamina, calcem et arenam, et dare et soluere ipsi magistro Iacobo pro suo salario, labore, premio et mercede libras sexagintaquinqe paruorum et quartas viginti frumenti et modia sex vini, in hiis tribus terminis et in hunc modum, videlicet, nunc ad presens libras quinque paruorum et frumentum et vinum in principio operis et libras sexaginta paruorum finito et conpleto toto ipso opere. Que omnia et singula predicta dicte partes solemnibus stipulationibus hinc inde interuenientibus promiserunt vicissim videlicet vna pars alteri et altera alteri ad inuicem firma, rata et grata habere, tenere, attendere, obseruare, adimplere et in nullo contrafacere, dicere uel uenire, per se uel per alios aliqua ratione uel de iure uel de facto, sub pena quarti euis de quo contrafactum fuerit, stipulatione promissa et reffectione et cetera, et obligatione et cetera, et pena soluta uel non et cetera, ad plenum... rogatus pro parte solutionis cuius premii dictus magister Iacobus fuit confessus a dicto ser Gregorio habuisse et recepisse libras quinque paruorum, renuntians exceptionis et cetera. Actum in platea magna.

(na margini) ser Simeon de Nosdrogna subscripsi

$$
I V \text {. }
$$

19. III. 1452.

Grgur Mrganić navodi uvjete predaje crkve sv. Mihovila na Zaglavu franjevcima trećorecima.

(Državni arhiv u Zadru, Zadarski bilježnici, Simon Damiani, b. III, fasc. 4, sv. 3, 130'131'; nepotpuno i s greškama objavljeno u ISPRAVE, dok. 5, str. 6-7)

(130') na margini: pro heremitis habitantibus in Insula magna in loco uocato Zaglaf, die XVIIII mensis marcii

Ser Gregorius Merganich ciuis Iadre ob reuerentiam omnipotentis Dei et sancti Micaelis archangeli ac pro salute anime sue dedit, concessit et assignauit in perpetuo fratri Paulo ministro, fratri Vito, fratri Martino, fratri Blaxio, ominus fratribus tercii ordinis 
sancti Francisci, ibidem presentibus et pro se suisque successoribus, cum voluntate, scitu, uerbo et licentia ser Anthonii de Grisogonis nobilis Iadre procuratoris et sindici eorum dictum fratrem, stipulantibus et recipientibus (131) [ a gornjoj margini: $\mathrm{M}^{\circ} \mathrm{CCCC}{ }^{\circ} \mathrm{XL}$ primo, indictione $\mathrm{XV}^{\mathrm{a}}$, ab incarnatione] vnum locum nuperime per ipsum ser Gregorium constructum et factum pro habitatione regularium personarum cum sua ecclesia, sub uocabulo sancti Micaelis, et cum orto gognalium duorum uel circa qui est iuxta ipsum locum positum in Insula magna in loco uocato Zaglaf districtus Iadre, et cum omnibus et singulis iuribus et pertinentiis ipsis loco et ecclesie spectantibus et pertinentibus, ad standum et habitandum et moram continuam faciendam in dicto loco. Et hoc ideo quod dicti fratres per se suosque successores, cum uoluntate dicit ser Anthonii, promiserunt et se obligauerunt ipsi ser Gregorio pro se suisque heredibus et successoribus stipulanti ibi stare et suam stabilem mansionem perpetuo facere et habere et tenere, apud se unum sacerdotem idoneum qui missam quotidie celebrabit et alia diuina officia dicet et faciat. Quod si ipsi fratres per se uel suos successores ibi non tenebunt, aliqua eorum malitia, culpa seu deffectu, vnum sacerdotem idoneum qui diuina officia celebrabit ut predictum, quod ipse ser Gregorius in tali casu per se suosque heredes et succesores possit et ualeat sua propria auctoritate ipsos fratres de dicto loco licenciare et expellere pro libito uoluntatis sue. Verum si contigerit quod ipsi fratres haberent aliquod iustum impedimentum, quo obstante non possent habere, seu inuenire aliquem idoneum sacerdotem qui ibi dicta diuina officia celebraret, quod eo casu dictus ser Gregorus per suosque heredes et succesores non possit nec ualeat neque debeat ipsos fratres uel eorum successores de dicto loco expellere neque licentiare, tamen ipsis fratres per se suosque successores omnio debeant et teneantur quod primum eis fuerit possibile inueniendo aliquem bonum et honestum sacerdotem ac idoneum qui ibi simul cum eis stabit et diuina officia omnia celebrabit, et hoc ideo quod sit inter eos fuit actum et conuentum. Que omnia et singula predicta dicte partes promiserunt incissim videlicet una pars alteri (131') [na gornjoj margini: $\mathrm{M}^{\circ} \mathrm{CCCC}^{\circ} \mathrm{XL}$ primo, indictione $\mathrm{XV}^{\mathrm{a}}$, ab incarnatione] et altera alteri ad inuicem solemnibus stipulationibus hinc inde interuenientibus semper firma, rata et grata habere et tenere, obseruare et adimplere et in nullo contrafacere, dicere uel uenire, per se uel alios aliqua ratione uel causa de iure uel de facto, sub pena quarti hinc inde et ad inuicem inter ipsas partes stipulata et promissa soluenda a parte contrafaciente parti predicta seruanti et reffectione hinc inde damnorum omnium intresse et expensarum litis et extra, et obligatione hinc inde omnium suorum bonorum dicti ser Gregorii et dictorum fratrum mobilium et immobilium presentium et futurorum, et pena soluta uel non, omnia contenta in presenti instrumento nichilominus obtineant, plenum robor. Actum Iadre in domo habitationis dicti ser Anthonii de Grisogonis, presentibus ser Blasio Petri et Georgio Stoyci, merzariis, ciuibus et habitatoribus Iadre, testibus ad pacta uocatis et rogatis.

(drugi rukopis) Ego Michael de Pechiaro iudex examinator Iadre me subscripsi

(na margini) ser Michael de Pechiaro examinator 


\section{Bibliografija}

\section{Neobjavljeni izvori}

Državni arhiv u Zadru. Zadarski bilježnici: Artikucije iz Rivinjana (1383-1416), Iohannes de Calcina (1439-1492), Nicolaus de Benedicti (1433-1469), Simon Damiani (1440-1476), Teodorus de Prandino (1403-1441).

\section{Objavljeni izvori}

ANČIĆ, Mladen. 2005. Splitski i Zadarski kaptol kao ,vjerodostojna mjesta“. U Registar Artikulacija iz Rivignana [Srednjovjekovni registri Zadarskog i Splitskog kaptola, sv. 1]. Fontes 11: 11-77.

AR ACI: U ANČIĆ 2005: 80-313.

CD CDS: SMIČIKLAS, Tadija. 1912. Codex diplomaticus regni Croatiae, Dalmatiae et Slavoniae, vol. 10. Zagreb: Jugoslavenska akademija znanosti i umjetnosti.

INVENTAR: U STIPIŠIĆ 2000: 35-252.

ISPRAVE: U IVANČIĆ 1910: 3-162.

IT-TPACI: KARBIĆ Damir, Maja KATUŠIĆ, Ivan MAJNARIĆ. 2012. Zajednički registar Ivana de Trottisa i Teodora de Prandina [Srednjovjekovni registri Zadarskog i Splitskog kaptola, sv. 4]. Fontes 18: 7-153.

IT-TP ACIb: KARBIĆ Damir, Maja KATUŠIĆ, Ivan MAJNARIĆ. 2012. Zajednički registar Ivana de Trottisa i Teodora de Prandina [Srednjovjekovni registri Zadarskog i Splitskog kaptola, sv. 4]. Fontes 18: 155-194.

LJETOPIS: ŠIŠIĆ, Ferdo. 1904. Ljetopis Pavla Pavlovića patricija zadarskog. Vjesnik Kr. hrvatsko-slavonsko-dalmatinskoga zemaljskoga arkiva 6: 2-59.

OPORUKA: U JELIĆ 1960: 502-507.

PP ACI: KARBIĆ Damir, Maja KATUŠIĆ, Ana PISAČIĆ. 2007. Velika bilježnica Zadarskog kaptola [Srednjovjekovni registri Zadarskog i Splitskog kaptola, sv. 2]. Fontes 13: 5-296.

ZS: KOLANOVIĆ, Josip, Mate KRIŽMAN. 1997. Zadarski statut: sa svim reformacijama, odnosno, novim uredbama donesenima do godine 1563. Zadar, Zagreb: Matica hrvatska, Hrvatski državni arhiv.

\section{Literatura}

ANČIĆ, Mladen. 1997. Ser Ciprijan Zaninov. Rod i karijera jednog splitskog patricija druge polovice XIV. stoljeća. Radovi Zavoda za povijesne znanosti HAZU u Zadru 39: 37-80.

ANČIĆ, Mladen. 2009. Od tradicije ,sedam pobuna“ do dragovoljnih mletačkih podanika Razvojna putanja Zadra u prvome desetljeću 15. stoljeća. Povijesni prilozi 28/37: 43-96.

ANTOLJAK, Stjepan. 1992. Hrvati u prošlosti. Split: Književni krug.

BARABÁSI, Albert-László. 2002. Linked: the new science of networks. Cambridge: Perseus publishing. 
BARNARD Alan, Anthony GOOD. 1984. Research practices in the study of kinship. London-Orlando: Academic Press.

BENYOVSKY LATIN, Irena. 2007. Uloga bratovštine Sv. Duha u Trogiru u srednjem i ranom novom vijeku. Povijesni prilozi 26/32: 25-61.

BOWDON, Lynne. 2004. Redefining Kinship: Exploring Boundaries of Relatedness in Late Medieval New Romney. Journal of Family History 29/4: 407-420.

CARSTEN, Janet (ed.). 2000. Cultures of relatedness: new approaches to the study of kinship. Cambridge-New York: Cambridge University Press.

DEVERE, Heather. 2013. The Academic Debate on Friendship and Politics. AMITY: The Journal of Friendship Studies 1: 5-33.

FABIJANEC, Sabine F. 1999. Profesionalna djelatnost zadarskih trgovaca u XIV i XV stoljeću. Zbornik Odsjeka za povijesne znanosti Zavoda za povijesne i društvene znanosti HAZU 17: 31-60.

FABIJANEC, Sabine F. 2004. Društvena i kulturna uloga zadarskog trgovca u XIV. i XV. stoljeću. Zbornik Odsjeka za povijesne znanosti Zavoda za povijesne i društvene znanosti HAZU 22: 55-120.

FISKOVIĆ, Cvito. 1959. Zadarski sredovječni majstori. Split: Pododbor Matice hrvatske.

GRBIN, Nedo. 1998. Glagoljica crkve i samostana sv. Mihovila u Zaglavu. U Zaglav: 600 godina prvog spomena: 540 godina posvete crkve svetog Mihovila Arhanđela, ur. Dino Čuka, Cvjetko Milanja, Izak Špralja, 67-92. Zaglav: Općina Sali, Mjesni odbor Zaglav.

HASELDINE, Julian P. 2013. Friendship Networks in Medieval Europe: New models of a political relationship. AMITY: The Journal of Friendship Studies 1: 69-88.

HERLIHY, David. 1973. Three Patterns of Social Mobility in Medieval History. The Journal of Interdisciplinary History 3/4: 623-647.

HILJE, Emil. 2003. Utemeljenje franjevačkih samostana na zadarskim otocima. Radovi Zavoda za povijesne znanosti HAZU u Zadru 45: 7-19.

HILJE, Emil. 2005. Zadarski graditelj Vidul Ivanov i njegovi sinovi. Radovi Zavoda za povijesne znanosti HAZU u Zadru 47: 149-190.

IVANČIĆ Stjepan. 1910. Povjestne crte o samostanskom III Redu sv. O. Franje po Dalmaciji, Kvarneru i Istri i poraba glagolice u istoj redodržavi: sa prilozima. Zadar: Tisk. E. Vitaliani.

JANEKOVIĆ RÖMER, Zdenka. 1999. Okvir slobode: dubrovačka vlastela između srednjovjekovlja i humanizma. Zagreb-Dubrovnik: Zavod za povijesne znanosti Hrvatske akademije znanosti i umjetnosti u Dubrovniku.

JANEKOVIĆ RÖMER, Zdenka. 2013. Udobni dom suknara Mihovila Petrovog: svakodnevica bogate građanske obitelji u anžuvinskom Zadru. Istarski povijesni biennale 5: 9-29.

JANEKOVIĆ RÖMER, Zdenka. 2014. Ser Micouillus Petri, draparius, civis Iadre - život kao znak vremena. Radovi Zavoda za povijesne znanosti HAZU u Zadru 56: 45-68.

JELIĆ, Roman. 1960. Grgur Mrganić. Radovi Instituta JAZU u Zadru 6-7: 487-508.

KARBIĆ, Damir. 2000. The Šubići of Bribir: A Case Study of a Croatian Medieval Kindred. Ph. D. diss., Central European University. 
MCNEILL, John Robert, William H. MCNEILL. 2003. The human web: a bird's-eye view of world history. New York-London: W.W. Norton.

MAJNARIĆ, Ivan. 2012. Srednje i niže plemstvo u širem zadarskom zaleđu od polovice XIV. do polovice XV. stoljeća. Doktorska disertacija. Filozofski fakultet, Sveučilište u Zagrebu.

MAJNARIĆ, Ivan. 2014. Nobility of the Croatian Kingdom between Zadar and Its Hinterland during the Late 14th and Early 15th Centuries. U Towns and Cities of the Croatian Middle Ages. Authority and Property, ed. Irena Benyovsky Latin, Zrinka Pešorda Vardić, 211-237. Zagreb: Croatian Institute of History.

MAJNARIĆ, Ivan. 2015. Kasnosrednjovjekovna obiteljska struktura hrvatskog plemstva. Povijesni prilozi 34/48: 7-31.

MCKEE, Sally. 2000. Uncommon dominion: Venetian Crete and the myth of ethnic purity. Philadelphia: University of Pennsylvania Press.

MULLETT, Margaret. 2005. Power, Relations and Networks in Medieval Europe. Introduction. Revue belge de philologie et d'histoire 83/2: 255-259.

O'CONNELL, Monique. 2009. Men of empire: power and negotiation in Venice's maritime state. Baltimore: Johns Hopkins University Press.

PEDERIN, Ivan. 1990. Mletačka uprava, privreda i politika u Dalmaciji (1409.-1797.). Dubrovnik: Časopis „Dubrovnik“.

PEŠORDA VARDIĆ, Zrinka. 2007. „Pučka vlastela“: društvena struktura dubrovačke bratovštine Sv. Antuna u kasnom srednjem vijeku. Povijesni prilozi 26/33: 215-237.

PETRICIOLI, Ivo. 1974. Građevni i umjetnički spomenici srednjega vijeka na zadarskim otocima. U Zadarsko otočje, ur. Valentin Uranija, 79-108. Zadar: Narodni muzej.

RAUKAR, Tomislav. 1977. Zadar u XV. stoljeću. Ekonomski razvoj i društveni odnosi. Zagreb: Sveučilište, Centar za povijesne znanosti, Odjel za hrvatsku povijest.

RAUKAR, Tomislav. 2007. Studije o Dalmaciji u srednjem vijeku: odabrane studije. Split: Književni krug.

RUNJE, Petar. 1998. O šestotoj godišnjici Zaglava. U Zaglav: 600 godina prvog spomena: 540 godina posvete crkve svetog Mihovila Arhanđela, ur. Dino Čuka, Cvjetko Milanja, Izak Špralja, 13-29. Zaglav: Općina Sali, Mjesni odbor Zaglav.

RUNJE, Petar. 2012. Prema izvorima II: rasprave i članci o hrvatskim franjevcima trećoredcima glagoljašima. Krk-Zagreb: Provincijalat franjevaca trećoredaca, Povijesno društvo otoka Krka.

SCOTT, John. 2000. Social network analysis: a handbook. London-Thousand Oaks: SAGE Publications.

STIPIŠIĆ, Jakov. 1984. Prvi poznati dodir s Danteom u Hrvata. U Dante i slavenski svijet, sv. 2, ur. Frano Čale, 629-637. Zagreb: Jugoslavenska akademija znanosti i umjetnosti, Razred za suvremenu književnost.

STIPIŠIĆ, Jakov. 2000. Inventar dobara Mihovila suknara pokojnog Petra iz godine 1385. Zadar: Stalna izložba crkvene umjetnosti u Zadru. 
VEKARIĆ, Nenad i dr. 2000. Vrijeme ženidbe i ritam poroda (Dubrovnik i njegova okolica od 17. do 19. stoljeća). Zagreb-Dubrovnik: Hrvatska akademija znanosti i umjetnosti, Zavod za povijesne znanosti u Dubrovniku.

WASSERMAN, Stanley, Katherine FAUST. 1994. Social network analysis: methods and applications. Cambridge: Cambridge University Press.

\section{Zaglav Foundation of St. Michael from Grgur Mrganić's Point of View}

In March 1452 Grgur Mrganić, a wealthy merchant from Zadar, donated the newly built church of St. Michael in Zaglav on the island of Dugi otok to Franciscan Tertiaries. This private foundation, consecrated in 1458 and endowed with Mrganić's bequest in 1460, has been in continuous use ever since, apart from a period when it was closed between 1843 and 1888. Although the history of the church building and the establishment of the community in the middle of the $15^{\text {th }}$ century is in largely well known, the context of Mrganić's undertaking and his motives were explored only in passing and in most cases, although correctly, they were limited to the framework of his charity, personal fortune and concern for the afterlife. Therefore, the present paper will be dealing with the wider context of Mrganić's deed, taking into consideration his ancestry, social status and the administrative circumstances in Zadar in the middle of the $15^{\text {th }}$ century.

Ključne riječi: XV. stoljeće, mletački Zadar, pučani, franjevci, Grgur Mrganić.

Keywords: $15^{\text {th }}$ century, Zadar under the Venetians, commoners, Franciscans, Grgur Mrganić.

Ivan MAJNARIĆ Hrvatsko katoličko sveučilište Ilica 242

HR-10000 Zagreb ivan.majnaric@unicath.hr 


\section{FILOZOFSKI FAKULTET SVEUČILIŠTA U ZAGREBU \\ ZAVOD ZA HRVATSKU POVIJEST \\ INSTITUTE OF CROATIAN HISTORY \\ INSTITUT FÜR KROATISCHE GESCHICHTE}

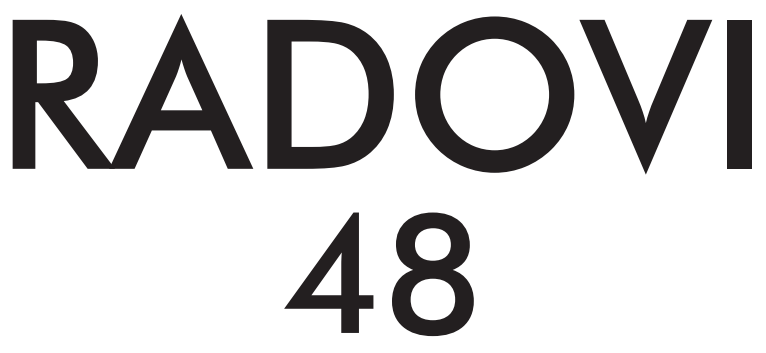

ZAVOD ZA HRVATSKU POVIJEST

FILOZOFSKOGA FAKULTETA SVEUČILIŠTA U ZAGREBU

\section{FF press}

ZAGREB 2016. 


\title{
RADOVI ZAVODA ZA HRVATSKU POVIJEST FILOZOFSKOGA FAKULTETA SVEUČILIŠTA U ZAGREBU \\ Knjiga 48
}

\author{
Izdavač / Publisher \\ Zavod za hrvatsku povijest \\ Filozofskoga fakulteta Sveučilišta u Zagrebu \\ FF-press \\ Za izdavača / For Publisher \\ Željko Holjevac \\ Glavni urednik / Editor-in-Chief \\ Hrvoje Gračanin \\ Izvršna urednica / Executive Editor \\ Inga Vilogorac Brčić \\ Uredništvo / Editorial Board
}

Bruna Kuntić-Makvić (stara povijest/ancient history), Zrinka Nikolić Jakus (srednji vijek/ medieval history), Hrvoje Petrić (rani novi vijek/early modern history), Željko Holjevac (moderna povijest/modern history), Tvrtko Jakovina (suvremena povijest/contemporary history),

Silvija Pisk (mikrohistorija i zavičajna povijest/microhistory and local history),

Zrinka Blažević (teorija i metodologija povijesti/theory and methodology of history)

Međunarodno uredničko vijeće / International Editorial Council

Denis Alimov (Sankt Peterburg), Živko Andrijašević (Nikšić), Csaba Békés (Budapest), Rajko Bratož (Ljubljana), Snježana Buzov (Columbus, Ohio), Svetlozar Eldarov (Sofija), Toni Filiposki (Skopje), Aleksandar Fotić (Beograd), Vladan Gavrilović (Novi Sad), Alojz Ivanišević (Wien),

Egidio Ivetić (Padova), Husnija Kamberović (Sarajevo), Karl Kaser (Graz),

Irina Ognyanova (Sofija), Géza Pálffy (Budapest), Ioan-Aurel Pop (Cluj),

Nade Proeva (Skopje), Alexios Savvides (Kalamata), Vlada Stanković (Beograd), Ludwig Steindorff (Kiel), Peter Štih (Ljubljana)

\section{Izvršna urednica za tuzemnu i inozemnu razmjenu / Executive Editor for Publications Exchange \\ Kristina Milković}

Tajnik uredništva / Editorial Board Assistant
Dejan Zadro

Adresa uredništva/Editorial Board address

Zavod za hrvatsku povijest, Filozofski fakultet Zagreb, Ivana Lučića 3, HR-10 000, Zagreb

Tel. ++385 (0)1 6120 150, 6120 158, faks ++385 (0)1 6156879

Časopis izlazi jedanput godišnje / The Journal is published once a year

Časopis je u digitalnom obliku dostupan na / The Journal in digital form is accessible at Portal znanstvenih časopisa Republike Hrvatske „Hrčak“ http://hrcak.srce.hr/radovi-zhp

Financijska potpora za tisak časopisa / The Journal is published with the support by

Ministarstvo znanosti, obrazovanja i športa Republike Hrvatske

Časopis je indeksiran u sljedećim bazama / The Journal is indexed in the following databases:

Directory of Open Access Journals, EBSCO, SCOPUS, ERIH PLUS, Emerging Sources Citation Index - Web of Science 


\section{Naslovna stranica}

Iva Mandić

Grafičko oblikovanje i računalni slog

Marko Maraković

\section{Lektura}

Samanta Paronić (hrvatski / Croatian)

Dražen Nemet (engleski / English)

Tisak

Tiskara Zelina d.d., Sveti Ivan Zelina

Naklada

250 primjeraka

Časopis je u digitalnom obliku dostupan na Portalu znanstvenih časopisa Republike Hrvatske ,Hrčak" http://hrcak.srce.hr/radovi-zhp

The Journal is accessible in digital form at the Hrcak - Portal of scientific journals of Croatia http://hrcak.srce.hr/radovi-zhp 


\section{RADOVI 48}

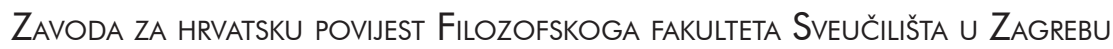

